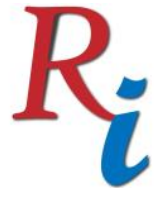

Asia Proceedings of Social Sciences

(APSS)

www.readersinsight.net/APSS

\title{
THE EFFECT OF DigITAL UnSECURED LOANS AND DTI RATIO ON RISK-TAKING BEHAVIOR
}

\author{
Yandra, Fachmi Pachlevi ${ }^{\star}$
}

Department of Accounting YKPN School of Business Indonesia

\section{Sopacua, Ivana Oktarina}

Department of Accounting YKPN School of Business Indonesia

*Corrosponding author's Email: pachlevi18@gmail.com

Peer-review under responsibility of 5th ${ }^{d}$ Asia International Conference 2019 Scientific Committee http://connectingasia.org/scientific-committee/ (C) 2019 Published by Readers Insight Publisher, lat 306 Savoy Residencia, Block 3 F11/1,44000 Islamabad. Pakistan, editor@readersinsight.net This is an open access article under the CC BY-NC-ND license (http://creativecommons.org/licenses/by-nc-nd/4.0/). 


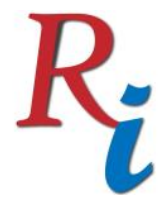

Asia Proceedings of Social Sciences

(APSS)

www.readersinsight.net/APSS

\section{A b s t r a c t}

The objective of this study was to examined the effect of digital unsecured loans and DTI ratio on changes in risk-taking behavior of the household sectros. Increasing of P2P lending is clearly unstoppable in Indonesia. Digital unsecured loans success to simplify credit process, because online-based credit aplication. However, these simply process are followed by highinterest rate. Many people apply for credit without considering risk. The convenience of digital unsecured loans making people forget about high annual percentage rate. Finally, occur increase potential bad loans in the household sectros. Collection of data was carried out through experiments $2 \times 2$ factorial design. The results shows that digital unsecured loans increases risk-taking behavior of household sectors. DTI ratio also can be used as an internal control of household sectors to prevent increased risk-taking behavior.

\section{Research High I ight s}

This study prove negative impact of digital unsecured loans on risk-taking behavior. This study also prove that DTI ratio can mitigate individual risk taking behavior in condition there is digital unsecured loans. This study proposed three hypothesis and the results indicated there was significat difference (for all hypothesis) about mean scores of subject intention to apply digital unsecured loans between manipulation and control group.

\section{Research Objectives}

Previous studies on non-performing loans (NPL) showed that NPL has negative effect on economic growth (see Erdoğdu, 2017; Balgova et al., 2018). Studies on NPL also analyzed factors influenced level of NPL (see Makri et al., 2014; Rehman, 2017; Waqas et al., 2019). However, these studies only focus on economic variables. NPL might be also influenced by psychological factors such as bahvioral take risks. The purpose of this study was to conduct laboratory experiment to examine the effect of digital unsecured loans and DTI ratio toward risk-taking behavior. Specifically, this study compared mean scores of individual risk-taking behavior between subjects in condition with and without (digital unsecured loans/DTI ratio). 


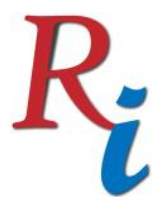

Asia Proceedings of Social Sciences

(APSS)

www.readersinsight.net/APSS

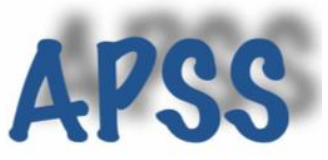

In addition, this study also examined moderation effect of DTI ratio on digital unsecured loans and risk-taking behavior relationship.

\section{Methodology}

Laboratory-experiment 2 × 2 factorial design was adopted to carry out the study. Experimental method will give the clarity about causality conslusions from manipulation independent variable (Nahartyo, 2009). This study aims to examined the causal effect between digital unsecured loans and DTI ratio on risk-taking behavior, then experimental method was appropriate. Task of experimental was simulation of short-term credit application. Participants have to determine how much their intention to apply credit base on various information. Manipulation of independent variables induced to participant through information on experimental task. Dependent variable was risk-taking behavior, measured using Likert scale $(1-10)$ about subjects intention to apply credit. Independent variables was digital unsecured loans and DTI ratio. All independents variables were manipulated to subjects in the manipulation group through case materials they receive.

\section{Results}

The result of this study showed that main effect of digital unsecured loans on risk-taking behavior was significant with $\mathrm{F}=8.92 ; \mathrm{p}=0.004$. Digital unsecured loans was proven causes significant increases in risk-taking bahavior. Hypothesis 1 was supported. Main effect of DTI ratio also significant with $\mathrm{F}=4.54 ; \mathrm{p}=0.03$. DTI ratio was proven causes significant reduction of risk-taking behavior. Hypothesis 2 was supported. Interaction effect between digital unsecured loans and DTI ration on risk-taking behavior was not significant wit $\mathrm{F}=0.262 ; \mathrm{p}=$ 0.611. However, mean score of subjects in group manipulation (digital unsecured loans \& DTI ratio) was lower and significantly difference than subjects in group manipulation (digital unsecured loans $\&$ no DTI ratio). T-test showed that t score $=2.067 ; \mathrm{p}=0.04$. In condition digital unsecured loans presence, subject who consider DTI ratio showed lower risk-taking behavior than subjects who don't. Hypothesis 3 was supported. 


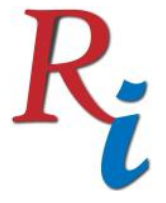

Asia Proceedings of Social Sciences

(APSS)

www.readersinsight.net/APSS

\section{Findings}

Digital unsecured loans presence in the digital era has been shown to increase risk-taking behavior of financial subject in the household sectors. DTI ratio was proven to be an internal control mechanism to household sectors in evaluating risk from credit facilities, especially digital unsecrud loans.

\section{References}

Balgova, M., Nies, M., \& Plekhanov, A. (2018). The Economic Impact of Reducing NonPerforming Loans. SSRN Electronic Journal, (193).

Erdoğdu, A. (2017). Assessing the Impact of Non-Performing Loans on Economic Growth in Turkey. American Research Journal of Business Management, 2016, 1-8.

Makri, V., Tsagkanos, A., \& Bellas, A. (2014). Determinants of non-performing loans: The case of Eurozone. Panoeconomicus, 61(2), 193-206.

Nahartyo, E. (2009). Budgetary Participation and Stretch Targets : Procedural Fairness in A Stretch Budget Condition. Journal of Economics and Finance, p. 16, 32-47.

Rehman, O. U. (2017). Determinants of Non-Performing Loan in South Asia: The Role of Financial Crisis. Eurasian Journal of Business and Economics, 10(20), 105-124.

Waqas, M., Fatima, N., Khan, A., \& Arif, M. (2019). Determinants of Non-performing Loans. International Journal of Finance \& Banking Studies (2147-4486), 6(1), 51-68. 